\title{
Inquiry-Based Learning for Improving Student Learning Outcomes: Literature Review
}

\author{
Seftiani Utami ${ }^{1, a)}$, Sri Sundari ${ }^{2}$ \\ ${ }^{1}$ Master Student in Nursing, Postgraduate Program, Universitas Muhammadiyah Yogyakarta \\ ${ }^{2}$ Lecturer, Faculty of Nursing and Health Sciences, Universitas Muhammadiyah Yogyakarta \\ $\bowtie:{ }^{\text {a) }}$ seftianiutami15@gmail.com
}

\begin{abstract}
The learning process has entered the 21st century and shifted from Teacher Center Learning (TCL) to Student Center Learning (SCL). Therefore, to improve student learning achievement and activity, innovative learning models are needed to provide more active learning opportunities for students in the learning process. There are several innovative learning models, one of which can improve student achievement and activity is inquiry-based learning. It would be better for students to discuss lessons or try to learn the material first, then present the results in front of the class and discuss with other students. Thus, the learning process becomes more active and dynamic with the guidance and direction of the lecturer. This literature review aims to determine the influence of the application of inquiry learning in improving student learning outcomes. The design used is a literature review, articles are collected using the database ProQuest, google scholar, and Science Direct with the keywords "inquiry-based learning model" and "learning outcomes." The criteria for the articles used are those published in 2014-2018. Based on thirteen articles collected, the results showed that ten articles showed that inquiry learning improved student learning outcomes while the other three did not influence student learning outcomes, but could increase learning motivation. Inquiry-based learning involves students directly and actively in the learning process so that learning has a significant effect on improving learning outcomes.
\end{abstract}

Keywords: inquiry-based learning, learning outcome, literature review

\section{INTRODUCTION}

Several studies showed that education models designed for the education needs were not suitable to answer the challenges and opportunities presented to the 21st-century students (Pendidikan Alberta 2010; Barron \& Hammond 2008; Friesen \& Jardine 2009; Perkins 2009). A new educational environment requires a different way to design learning experiences for students and also a new approach in teaching and evaluating. There were changes in the learning process in early 21 st-century education. The learning process was centered on the student center learning (SCL) and no longer focused on the teacher center learning (TCL). The 21st century demands a loaded technology and information which leads to the development of the education system. Competence of students in the 21 st century is also growing, including thinking skills and action proficiency (Istikomayanti and $\mathrm{Si}$ 2015). The aim of inquiry-based as another teaching method used in science education is improving 
the mental will of the students. The U.S. National Science Education Standards recommend inquirybased science teaching strategies for encouraging students to explore and construct their scientific knowledge. Research also demonstrates that inquiry-based instruction has a positive effect on student learning outcomes, leading many scholars to believe that inquiry is the best strategy for science education (Ince and Acar 2016).

A particular study program of subject and Inspiring Education's document (2010) from the Ministry of Education states that education vision is preparing the young generation for changes in the economy, technology, and socio-political realities in the 21st century. Through developing intellectual involvement, entrepreneurial spirit, and disposition of ethical citizenship, the education vision described in the Inspiring Education's document advocates students to develop their competencies through research and discovery process. Students are collaborating to create new knowledge, also learning "how to think critically and creatively, and how to make a discovery - through research, reflection, exploration, experiment, and trial" (Alberta Education 2010).

Learning activities in a lecture are active interaction between lecturers and students. The duty and responsibility of a lecturer are to manage a learning process effectively, dynamically, and efficiently, which is characterized by the active involvement of the students. Lecturers provide guidance and direction to the students to actively seek information on the material which is learned, and they can learn independently (Putra and Purwasih 2015). However, during a lecture, there are still lecturers who always present and explain the subject, while students only take notes and pay attention. This kind of learning activity creates passive students. They are not required to prepare and study the material before class so that when the lecturer explains, the students do not know to discuss together in the class. It is better if the students try to learn the material first, then, present the results of their work in front of the class, and discuss with other students. Therefore, the atmosphere of the lecture becomes active and dynamic with the guidance and direction of the lecturer (Putra and Purwasih 2015) For student achievement and activity, an innovative learning model needs to be pursued which allows students to be more active in the learning process. From so many innovative learning models, there is one model to improve student achievement and activity, which is inquiry-based learning. There are several main characteristics and advantages of the Inquiry learning model. First, the inquiry strategy emphasizes student activity to the maximum to search and find problems. It means that the inquiry approach puts students as the subject of learning. Next, all of activities carried out by students are directed to search and find by themselves from a questionable thing, so that it is expected to foster self-confidence (selfbelieve) and they can learn independently. Third, the purpose of utilizing an inquiry learning strategy is to develop intellectual abilities as part of mental processes. Consequently, in inquiry learning, students are not only required to master the subject but how they can use their potential (Sari 2015).

According to the study of Nybo and May (2015), inquiry-based learning approaches are more beneficial for student learning outcomes than through a provision of traditional instruction. While according to Triyana (2017), the guided inquiry model is more effective than the PBL (problem-based learning) model for problem-solving abilities. A study by Hartini (2016) argues that there are significant differences in learning outcomes between the use of inquiry and PBL learning models. The difference can be seen from the average value of the learning outcomes of the experimental class I using the inquiry learning model is better than the experimental class II, which uses the PBL model.

Inquiry-based learning requires students to solve real-world problems and to participate in tasks which reflect the work conducted by professionals in specific disciplines. With this new focus, formative assessments will help teachers modifying their teaching to help students obtain quality learning outcomes.

\section{METHODS}

The method used in the article search utilizes the Proquest database, Google Scholar, and Science Direct with the keywords "inquiry-based learning model" and "learning outcomes." There are 8563 articles from 2014-2018. There are 13 international journals which comply with the inclusion criteria. 
The initial selection process was screening the 8550 journals. There were 6329 journals based on the titles of the journals or articles which contained the words of "inquiry learning" or "learning outcomes." Those were excluded based on title to be 4672. After that, those were reviewed and re-read based on the abstracts, 1583 were deleted. There were 74 journals which were reviewed, and 61 were excluded because those did not meet the inclusion criteria. Finally, 13 journals are obtained which are following the inclusion criteria.

The inclusion criteria used in the selection of the literature review are as follows:

- Full text

- Research relates to inquiry-based learning methods which are implemented in students

- Provide information on the effect of inquiry-based learning on learning outcomes

- Journal from 2014-2018

\section{RESULTS}

The main focus of this literature review was the implementation of inquiry-based learning to improve learning outcomes. To optimize this interpretation, firstly, we clarified the findings. The search flow was summarized in the table figure.

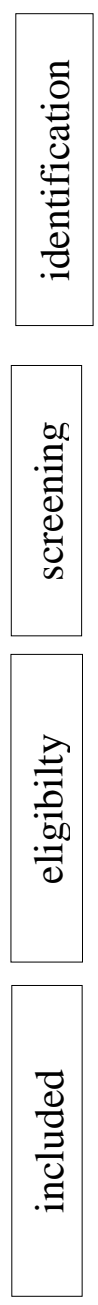

TABLE 1. ARTICLE SEARCH PROCESS

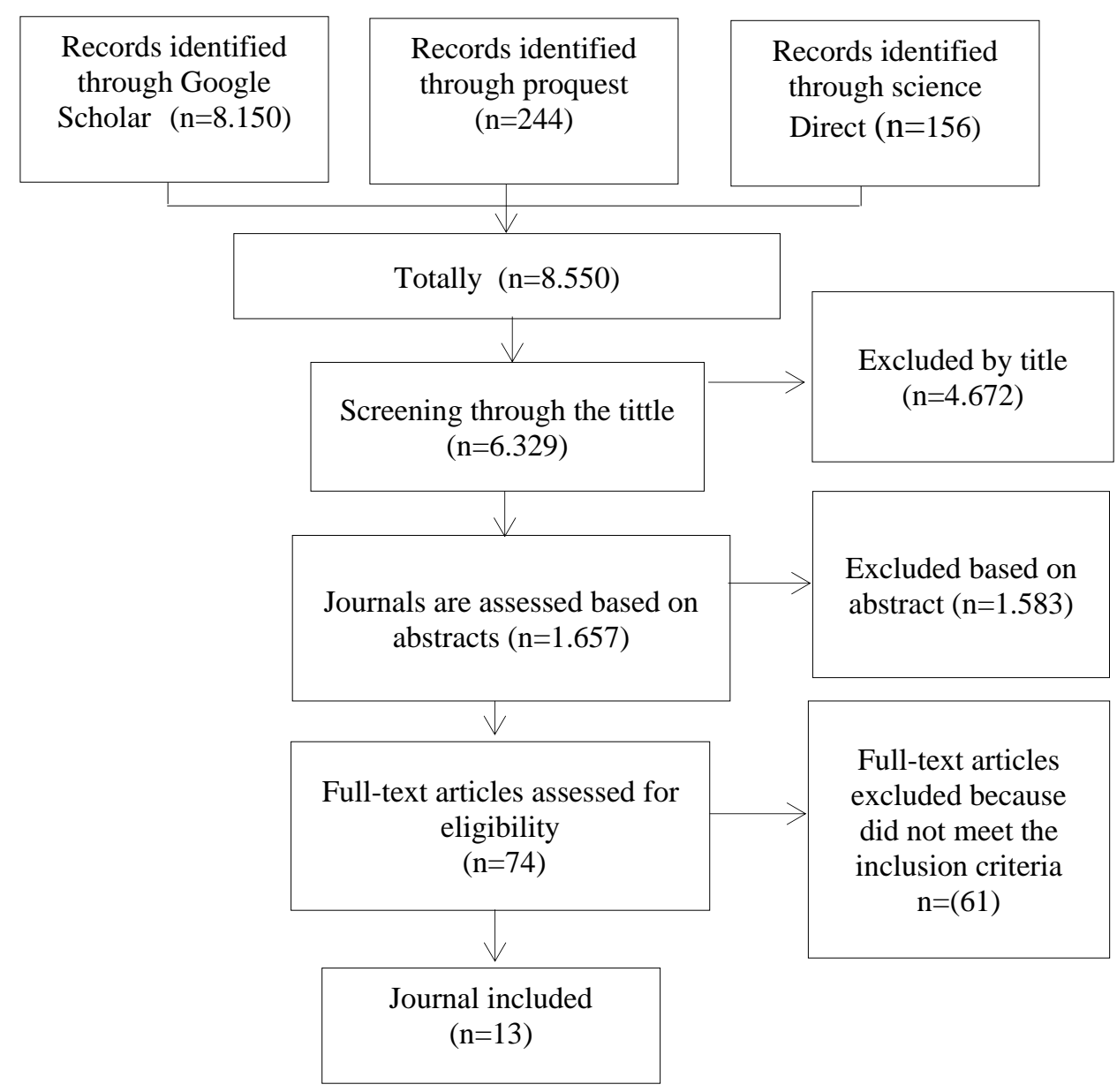


TABLE 2. STUDY CHARACTERISTICS

\begin{tabular}{|c|c|c|c|c|}
\hline Entitle & Purpose & Design & Respondent & Result \\
\hline $\begin{array}{l}\text { Development of an } \\
\text { Inquiry-Based } \\
\text { Learning Support } \\
\text { System Based on an } \\
\text { Intelligent } \\
\text { Knowledge } \\
\text { Exploration } \\
\text { Approach by (Wu } \\
\text { \&hwang. 2015) }\end{array}$ & $\begin{array}{l}\text { Support the system with two advanced } \\
\text { knowledge exploration modules: the Q\&A } \\
\text { module and the Segmented Supplemental } \\
\text { Material (SSM) module. This study } \\
\text { evaluates the effects of the proposed system } \\
\text { on students' learning achievement and } \\
\text { learning efficiency with the various } \\
\text { supports system. }\end{array}$ & $\begin{array}{l}\text { Quasi- } \\
\text { experiment }\end{array}$ & 90 people & $\begin{array}{l}\text { Both of the students' learning } \\
\text { achievement and their learning } \\
\text { efficiency were enhanced with } \\
\text { the support of the two advanced } \\
\text { modules }\end{array}$ \\
\hline $\begin{array}{l}\text { Effects Of Inquiry- } \\
\text { Based Learning } \\
\text { Activities On } \\
\text { Scientific Process } \\
\text { Skills And } \\
\text { Academic } \\
\text { Achievement Of } \\
\text { Preservice } \\
\text { Classroom Teachers } \\
\text { (Yildirim et al. } \\
\text { 2014) }\end{array}$ & $\begin{array}{l}\text { The purpose of whether inquiry-based } \\
\text { instruction affects scientific process skills } \\
\text { and improvement in academic performance } \\
\text { is better than traditional methods }\end{array}$ & $\begin{array}{l}\text { Quasi- } \\
\text { experiment }\end{array}$ & 44 people & $\begin{array}{l}\text { The result of the study, it was } \\
\text { determined that scientific inquiry- } \\
\text { based learning environments } \\
\text { affected scientific process skills } \\
\text { and increased } \\
\text { Academic achievement was better } \\
\text { than traditional method. } \\
\text { Additionally, the students in } \\
\text { scientific inquiry process } \\
\text { it is reported that they } \\
\text { participated more enthusiastically } \\
\text { and the lesson was fun for them. }\end{array}$ \\
\hline $\begin{array}{l}\text { Motivational } \\
\text { strategies in a } \\
\text { mobile inquiry- } \\
\text { based language }\end{array}$ & $\begin{array}{l}\text { This study examined how mobile inquiry- } \\
\text { based learning (M-IBL) influenced students' } \\
\text { learning motivation and achievement } \\
\text { following motivational theory }\end{array}$ & $\begin{array}{l}\text { Quantitative- } \\
\text { descriptive }\end{array}$ & 67 people & $\begin{array}{l}\text { The results indicated that } \\
\text { although there was no significant } \\
\text { difference in learning } \\
\text { achievement between the two } \\
\text { groups, the students who received }\end{array}$ \\
\hline
\end{tabular}




\begin{tabular}{|c|c|c|c|c|}
\hline Entitle & Purpose & Design & Respondent & Result \\
\hline $\begin{array}{l}\text { learning setting } \\
\text { (Chang et al. 2016) }\end{array}$ & & & & $\begin{array}{l}\text { M-IBL instruction with } \\
\text { motivational enhancement had } \\
\text { significantly higher learning } \\
\text { motivation than students who } \\
\text { received M-IBL instruction } \\
\text { without MSs. }\end{array}$ \\
\hline $\begin{array}{l}\text { The Implementation } \\
\text { of Pedagogical } \\
\text { Content Knowledge } \\
\text { (PCK) based Guided } \\
\text { Inquiry on Science } \\
\text { Teacher Students } \\
\text { (Biru et al. 2018) }\end{array}$ & $\begin{array}{l}\text { Examining the learning of Integrated } \\
\text { Sciences through PCK based guided inquiry } \\
\text { on prospective science teacher students. }\end{array}$ & $\begin{array}{l}\text { Qualitative- } \\
\text { descriptive }\end{array}$ & 33 people & $\begin{array}{l}\text { The results showed that the } \\
\text { implementation of the activities } \\
\text { of lecturer and science teacher } \\
\text { students during the learning } \\
\text { process using PCK based guided } \\
\text { inquiry was very good conducted. }\end{array}$ \\
\hline $\begin{array}{l}\text { 5E Mobile Inquiry } \\
\text { Learning Approach } \\
\text { for Enhancing } \\
\text { Learning Motivation } \\
\text { and Scientific } \\
\text { Inquiry Ability of } \\
\text { University Students } \\
\text { (Cheng et al. 2016) }\end{array}$ & $\begin{array}{l}\text { to encourage students } \\
\text { actively build knowledge through effective } \\
\text { inquiry learning by using mobile devices. }\end{array}$ & $\begin{array}{l}\text { Quasi- } \\
\text { experiment }\end{array}$ & 32 people & $\begin{array}{l}\text { The results showed no significant } \\
\text { difference in terms of academic } \\
\text { achievement, but the } 5 \mathrm{E} \text { mobile } \\
\text { inquiry had a positive impact on } \\
\text { participant motivation and ability } \\
\text { of scientific inquiry. }\end{array}$ \\
\hline $\begin{array}{l}\text { An epistemological } \\
\text { analysis of the } \\
\text { application of an } \\
\text { online inquiry-based } \\
\text { program in tourism }\end{array}$ & $\begin{array}{l}\text { This paper investigates the application of an } \\
\text { online inquiry-based program from an } \\
\text { epistemological perspective }\end{array}$ & quantitative & 50 people & $\begin{array}{l}\text { The online inquiry-based learning } \\
\text { (IBL) did change the participants' } \\
\text { epistemological beliefs } \\
\text { significantly, with a significant } \\
\text { effect }\end{array}$ \\
\hline
\end{tabular}




\begin{tabular}{|c|c|c|c|c|}
\hline Entitle & Purpose & Design & Respondent & Result \\
\hline \multicolumn{5}{|l|}{$\begin{array}{l}\text { education (Hsu } \\
\text { 2014) }\end{array}$} \\
\hline $\begin{array}{l}\text { An Investigation of } \\
\text { University Students' } \\
\text { Collaborative } \\
\text { Inquiry Learning } \\
\text { Behaviors in an } \\
\text { Augmented Reality } \\
\text { Simulation and a } \\
\text { Traditional } \\
\text { simulation (Wang et } \\
\text { al. 2014) }\end{array}$ & $\begin{array}{l}\text { The purpose of this study is to investigate } \\
\text { and compare students' collaborative inquiry } \\
\text { learning behaviors and their behavior } \\
\text { patterns in augmented reality (AR) } \\
\text { simulation system and a traditional 2D } \\
\text { simulation system. }\end{array}$ & Qualitative & 40 people & $\begin{array}{l}\text { The results of the content analysis } \\
\text { and LSA indicated that both } \\
\text { systems supported students' } \\
\text { collaborative inquiry learning. } \\
\text { Particularly, students showed } \\
\text { high frequencies on higher-level } \\
\text { inquiry behaviors, such as } \\
\text { interpreting experimental data or } \\
\text { making conclusions, when using } \\
\text { these two simulations. }\end{array}$ \\
\hline $\begin{array}{l}\text { Effectiveness of } \\
\text { inquiry-based } \\
\text { learning in an } \\
\text { undergraduate } \\
\text { exercise physiology } \\
\text { course (Nybo and } \\
\text { May 2015) }\end{array}$ & $\begin{array}{l}\text { The study investigates the effects of } \\
\text { changing a laboratory physiology course for } \\
\text { undergraduate students from a traditional } \\
\text { step-by-step guided structure to an inquiry- } \\
\text { based approach. }\end{array}$ & $\begin{array}{l}\text { Cross- } \\
\text { Sectional }\end{array}$ & 160 people & $\begin{array}{l}\text { The result shows that } \\
\text { although students are not familiar } \\
\text { with cardiorespiratory physiology } \\
\text { training and the experimental } \\
\text { method appears that inquiry- } \\
\text { based approaches can benefit } \\
\text { learning outcomes in } \\
\text { physiological laboratories rather } \\
\text { than providing students with } \\
\text { traditional instruction }\end{array}$ \\
\hline $\begin{array}{l}\text { The Effect of } \\
\text { Guided-Inquiry } \\
\text { Laboratory } \\
\text { Experiments on } \\
\text { Science Education }\end{array}$ & $\begin{array}{l}\text { The study aims to search the effect of } \\
\text { guided inquiry laboratory experiments on } \\
\text { students' attitudes towards chemistry } \\
\text { laboratory, chemistry laboratory anxiety, }\end{array}$ & Quantitative & 37 people & $\begin{array}{l}\text { The findings have revealed that as } \\
\text { a result of the applications, there } \\
\text { has been a significant increase in }\end{array}$ \\
\hline
\end{tabular}




\begin{tabular}{|c|c|c|c|c|}
\hline Entitle & Purpose & Design & Respondent & Result \\
\hline $\begin{array}{l}\text { Students' Chemistry } \\
\text { Laboratory } \\
\text { Attitudes, Anxiety, } \\
\text { and Achievement } \\
\text { (Ural 2016) }\end{array}$ & $\begin{array}{l}\text { and their academic achievement in the } \\
\text { laboratory. }\end{array}$ & & & $\begin{array}{l}\text { students' attitudes towards } \\
\text { chemistry laboratory, and their } \\
\text { academic achievement and a } \\
\text { decrease in their chemistry } \\
\text { laboratory anxiety. }\end{array}$ \\
\hline $\begin{array}{l}\text { Applying Anatomy } \\
\text { to Something I Care } \\
\text { About": Authentic } \\
\text { Inquiry Learning } \\
\text { and Student } \\
\text { Experiences of an } \\
\text { Inquiry Project } \\
\text { (Anstey, 2017) }\end{array}$ & $\begin{array}{l}\text { This article investigates authentic learning } \\
\text { in the context of an inquiry-based approach } \\
\text { to learning gross human anatomy }\end{array}$ & Qualitative & 18 people & $\begin{array}{l}\text { The results show how the project } \\
\text { greatly serves as a unique } \\
\text { learning experience in which } \\
\text { students are involved in the } \\
\text { opportunity to understand the } \\
\text { anatomy of the human body, } \\
\text { broader interdisciplinary interests, } \\
\text { and considerations through } \\
\text { collaboration, inquiry-based } \\
\text { learning. }\end{array}$ \\
\hline $\begin{array}{l}\text { The Effect Of } \\
\text { Guided Inquiry Vs } \\
\text { Free Inquiry } \\
\text { Instruction Method } \\
\text { And Learning } \\
\text { Motivation On } \\
\text { Student Learning } \\
\text { Outcomes (Yewang } \\
\text { 2017) }\end{array}$ & $\begin{array}{l}\text { this study aimed to examine the effect of } \\
\text { teaching methods and to learn motivation to } \\
\text { the learning outcomes of students in the } \\
\text { subject of accounting basics first semester } \\
\text { of economics education majors of FKIP } \\
\text { Undana }\end{array}$ & Experiment & 70 people & $\begin{array}{l}\text { The result show is an influence of } \\
\text { guided inquiry learning methods } \\
\text { vs. free inquiry against student } \\
\text { results. }\end{array}$ \\
\hline
\end{tabular}




\begin{tabular}{|c|c|c|c|c|}
\hline Entitle & Purpose & Design & Respondent & Result \\
\hline $\begin{array}{l}\text { Inquiry-based } \\
\text { learning to improve } \\
\text { student engagement } \\
\text { in a large first-year } \\
\text { topic (Smallhorn et } \\
\text { al. 2015) }\end{array}$ & $\begin{array}{l}\text { To Increasing the opportunity for students } \\
\text { to be involved in inquiry-based activities }\end{array}$ & Quantitative & 100 people & $\begin{array}{l}\text { The results suggest high levels of } \\
\text { student satisfaction and a } \\
\text { significant improvement in } \\
\text { student learning outcomes. }\end{array}$ \\
\hline $\begin{array}{l}\text { Enhancing Students' } \\
\text { Higher-Order } \\
\text { Thinking Skills } \\
\text { Through Guided and } \\
\text { Free Inquiry-Based } \\
\text { Learning (Yunistika } \\
\text { and Juanengsih } \\
\text { 2018) }\end{array}$ & $\begin{array}{l}\text { The study determined the effectiveness of } \\
\text { guided inquiry and free inquiry to improve } \\
\text { students' higher-order thinking skills } \\
\text { (HOTS) }\end{array}$ & $\begin{array}{l}\text { Quasi- } \\
\text { Experiment }\end{array}$ & 64 people & $\begin{array}{l}\text { The results showed a significant } \\
\text { improvement in students' thinking } \\
\text { skills and abilities of guided } \\
\text { inquiry and free inquiry learning } \\
\text { models. However, the two } \\
\text { learning models did not show a } \\
\text { significant difference }\end{array}$ \\
\hline
\end{tabular}




\section{Type of inquiry learning}

There are 13 articles that have been reviewed; two articles discussed Mobile inquiry-based learning (M-IBL). Mobile inquiry learning is inquiry learning supported by the use of mobile devices (Chang et al. 2016; Cheng et al. 2016), One article discusses an online inquiry learning that is learned using the web-based inquiry method (Hsu 2014), six articles discussed about inquirybased learning (Yildirim et al. 2014; Smallhorn et al. 2015; Anstey 2017; Biru et al. 2018; Wang et al. 2014; Nybo and May 2015), Three articles discussed about the guided inquiry and free inquiry (Yewang 2017; Yunistika and Juanengsih 2018; Ural 2016).

Guided inquiry learning is the teacher provides extensive guidance or instruction for the students. Teachers prepare the problem formulation as well as tools and materials. Investigation procedures are designed with the teachers and students. The students make observations to obtain data and test hypotheses. It obtained from observations, and then it is analyzed to make conclusions through group discussion. There are nine explains that guided inquiry used to:

1. study that prepare student for lifelong learning,

2. integrate with the content being studied,

3. to transmit the concept to obtain information,

4. using a variety of learning resources,

5. students perform the steps of learning from planning to final product,

6. connect directly between what is learned to the real world of students,

7. makes student learning communities that work together,

8. students and teachers collaborate, and

9. is process-oriented and results.

With these methods, students carry out an investigation based on the issues that have been well-prepared by teachers, and selection steps are determined by the student investigation. It can be said that the differences in student learning outcomes are influenced by the accuracy in the implementation of learning by using guided inquiry learning methods (Yewang 2017).

\section{Effect}

\section{The effectiveness of inquiry learning to the student learning outcomes}

Based on 13 articles that have been reviewed, 10 articles stated that inquiry learning could improve student learning achievement, the results of Wu and Hwang (2015) research showed inquiry learning with the support of two advanced modules can improve student learning achievement and their learning efficiency, research Yildirim et al. (2014) showed that scientific inquiry-based instruction affected scientific process skills and improved academic achievement better than traditional method. Additionally, the students in scientific inquiry process reported that they participated more enthusiastically and the lesson was fun for them.

Biru et al. (2018) showed that the implementation of the activities of lecturer and students activities during the learning process using PCK-based guided inquiry was excellent conduct. The result of Wang et al. (2014) showed the content analysis and lagged sequential analysis (LSA) indicated that the augmented reality (AR) simulation system and traditional 2D simulation systems supported student collaborative inquiry learning. Specifically, the students showed frequencies on higher-level inquiry learning behaviors, such as interpreting experimental data or making conclusions. Nybo and May (2015) revealed that inquiry-based learning could be beneficial for the learning outcomes in physiology laboratory.

The results of Ural (2016) declared that from inquiry learning there was a significant improvement such as improving academic achievement, students' attitudes were better when in the laboratory, and it could reduce the level of anxiety when performing laboratory work. Anstey (2017) demonstrated how inquiry learning is beneficial, where students are more active in learning to understand topic about the anatomy of the human body so the students' interest in learning is high and they have a disciplined attitude. Yewang (2017) said that there is an effect of free inquiry learning vs guided inquiry learning method to the student learning outcomes. The results of the study by Smallhorn et al. (2015) showed 
that inquiry learning increases the level of student satisfaction toward the learning process and a significant improvement in student learning outcomes. Yunistika and Juanengsih (2018) claimed that the guided inquiry learning model and free inquiry learning could improve students' thinking skills and learning abilities.

\section{The ineffectiveness of inquiry learning towards learning the outcome}

The research of (Chang et al. 2016) and (Cheng et al. 2016) showed that there was no significant difference in learning achievement between the control and experimental groups, but it demonstrates high motivation for learning. Hsu (2014) mentioned the possibility of the effectiveness of online IBL in helping tourism students develop more sophisticated epistemological beliefs, which may not be able to help students understand subject matter immediately but can facilitate better long-term retention.

\section{Duration and Period}

The duration and sessions of learning inquiry are different in each research. In several research studies, inquiry learning carried out for 50 minutes. Before starting learning, there would be 15 minutes pre-test to introduce the goal and the learning process in the class began for 50 minutes, and there would be a post-test one week after that (Wu and Hwang 2015).

The research of Chang et al. (2016) Mobile inquiry-based learning (M-IBL) is conducted every week, week one for the pre-test, two weeks for the introduction to M-IBL learning and one week for the learning process, one week for discussion and presentation of the last week of the post-test (Chang et al. 2016). During the first week, before beginning the experiment, the two classes completed a learning motivation scale and a scientific inquiry ability scale. The next four weeks had 2 hours per week of instruction in nanotechnology. At the end of the experiment, both scales were completed again as posttests (Cheng et al. 2016).

Inquiry learning online learning takes place 60 minutes, the post-test would be carried out 2 weeks after the experiment was given (Hsu 2014), guided inquiry duration of the course was 6 hours per week (4 laboratory hours plus 2 hours of theoretical study) (Ural 2016), a 13-week course explored structural human principles and function by observing microscopic and cardiovascular, respiratory, lymphatic, endocrine, digestive, and genitourinary anatomy. It consists of three components: lectures (50 minutes three times a week, a total of 39 hours), prosecution-based laboratory (one three-hour weekly lab, a total of 33 hours), and an Investigation Project (Anstey 2017), For the second six weeks the class uses guided and free inquiry learning (Yunistika and Juanengsih 2018).

It is conducted every week from three hours of laboratory sessions per two weeks to two hours of laboratory sessions per week. It increased the time students spent in the laboratory from 18 to 24 hours (Smallhorn et al. 2015), research conducted for 1 hour in the experimental class and 1 hour in traditional classes (Nybo and May 2015), while other research did not explain the duration and the period of the research conducted (Yildirim et al. 2014; Yewang 2017; Anstey 2017; Wang et al. 2014; Biru et al. 2018).

\section{DISCUSSIONS}

Several research studies have shown that the influence of inquiry learning instruction has a positive impact on student learning outcomes. Based on 13 articles reviewed, ten articles of them stated that inquiry learning affects student learning outcomes. Inquiry-based learning focuses on active learning of students. Their roles are changed from passive listeners to active explorers, while the teachers' roles are changed from the instructor to the problem-solving guide. The results of the study found that inquiry learning with the support of two advanced modules can improve student learning achievement and their learning efficiency (Wu and Hwang 2015). In inquiry-based learning activities, students develop hypotheses actively by themselves. They organize the learning environment together based on their plans, make observations, collect data, and obtain results. However, in traditional methods, students take a passive role; they only get what the teachers give. The Mann Whitney U test that was applied to the AAT post-test score of the experimental group and the control group showed that there were significant differences which showed a higher score of the experimental group. This 
result means that inquiry-based learning activities are effective in improving academic achievement (Yildirim et al. 2014).

Students who use inquiry learning are directed to search and find the answers to the questions so that it is expected to foster knowledge about something that is being studied. Furthermore, inquiry learning based on PCK can develop systematic, logical, and critical thinking skills or develop intellectual abilities (Biru et al. 2018). Inquiry learning consists of some stages including (1) Orientation: students can find information about the assignments given (2) make questions and identify problems about learning that are being studied (3) find solutions (4) interpretation of results (5) make conclusions (Wang et al . 2014).

The student in the achieved a higher $(\mathrm{p}<0.005)$ average score on the quantitative test, an Inquirybased approach that provides students with step-by-step instructions may benefit learning outcomes in a laboratory physiology course (Nybo and May 2015). Inquiry learning in the laboratory consisted of 1. Structured inquiry: The teachers prepare problems and the processes, 2. Guided inquiry: The teacher asks the students construct the solution process. 3. Open inquiry: Students determine the problem in the given context and try to solve it. The research studies that have been carried out reveals that as a result of the inquiry learning application at the laboratory, there has been a significant increase in students' laboratory activity, and their academic achievement but a decrease in their anxiety (Ural 2016). Inquiry learning is so functional for students as they are actively involved in understanding the anatomy of the human body and increasing interest in learning process (Anstey 2017).

Guided inquiry-based learning has the goal of developing and applying essential skills like problemsolving skills with self-study or teamwork and obtaining extensive knowledge and developing students' creativity and critical thinking. Guided inquiry learning methods can improve student learning outcomes; in this case, it can increase student participation. In addition to guided inquiry learning methods, learning methods that can improve critical thinking skills in problem-solving are free inquiry learning methods. The free inquiry learning method is a method where the teacher gives a problem, and students are required to solve the problem through observation and exploration to get the answer. Students do the solution on their initiative and ways (Yewang, 2017). Inquiry learning can improve student satisfaction and student learning outcomes in the laboratory. Inquiry-based learning is one of the teaching methods that must be considered in educational disciplines because it supports the independent learning of students. (Smallhorn et al., 2015).

Guided inquiry learning and free inquiry are the proper learning methods to improve thinking skills and academic abilities because students fully explore the knowledge learned actively and independently (Yunistika and Juanengsih, 2018). Three other studies conducted (Chang et al., 2016) and (Cheng et al., 2016) showed that there were no significant differences in learning achievement between the control and experimental groups, but there is a high increase in motivation for learning. The empirical results demonstrate that the experimental condition, 5E mobile inquiry learning, had a positive impact on participants 'learning motivation and scientific inquiry abilities. The research of (Hsu, 2014) showed the possible effectiveness of online IBL in helping tourism students'. It develops sophisticated epistemological beliefs. It may not be able to help learners comprehend the subject matter immediately but may facilitate better long-term retention. In another study on this issue Kocagül (2013) determined a significant development in teachers' scientific process skills. In this study determine the effects of inquiry-based learning method on conceptual understanding and scientific process skills of preservice physics teachers for the issue of electrical conductivity. The aim of inquiry-based learning in physics laboratories activities is to strengthen the minds of students. The students regard their teacher as experts who provide the correct answer in traditional thinking classes.

On the contrary, students construct their perception and take responsibility to create their information basis in the inquiry-based education environment. The teacher in this process is to enable easiness which enhances the learning of student. It emerged together with reform studies in teacher raising program especially in America after 2000. It was based on raising instructors. Both inquiries and make students inquire (NRC 2000). Inquiry-based learning is the most essential component of problem development in many countries right now. The various studies put the inquiry in science education includes processes of providing opportunities for students to create questions in order to reach the information they would construct within learning process. Inquiry-based learning in Physics 
laboratories was exhibited through determination of situations of teachers and pre-service teachers in practice process and studies on student success (Ince and Acar. 2016).

This literature explained that inquiry learning could improve student learning achievement, can increase learning motivation, higher-level inquiry behavior (such as making conclusions, interpreting experimental data), increasing student involvement in the learning process, and thinking skills. The review of the research literature found that to improve the learning outcome; the right inquiry learning method is needed by considering the type of inquiry learning, the duration of learning provided, and the required period of inquiry learning. Directly provided inquiry learning (e.g. guided inquiry) is more useful to use than mobile inquiry learning or online inquiry learning because free inquiry learning and online inquiry learning require a long time to introduce the device and for students to understand the lessons given through the mobile device or the website. However, as shown in the literature review, this review has not provided the right data for the duration, while the duration of inquiry learning is needed to improve student learning outcomes. Based on the discussion, a question arises whether the measurement scale in measuring learning outcomes is appropriate for evaluating the effects of inquiry learning. Whereas student learning outcomes are very dependent on people's character and may not be easily influenced in short-term training? Can inquiry learning be applied to the learning process in the field of nursing? Moreover, do students have to use inquiry learning to improve student academic learning outcomes? The answers to these questions can form the basis for further research studies on the method of inquiry learning and learning outcomes.

\section{CONCLUSIONS}

Based on the 13 journals obtained, 10 revealed the results that there was an influence of inquiry learning on student learning outcomes. This review literature shows that inquiry learning has a vital role in improving student learning outcomes because students are required to learn actively and solve problems so that they can obtain their learning goals. Thus, this literature review can be the basis for further research on inquiry learning methods and student learning outcomes in order to use a broader range of sources.

\section{LIMITATIONS}

Based on the discussion of this literature, only English researchers can study with the full text available. Because experimental research is a high-quality student limited to this agreement.

\section{REFERENCES}

Alberta Education. (2010). Inspiring education: A dialogue with Albertans. Edmonton, AB: Alberta Education.

Anstey, L.M., 2017. "Applying anatomy to something I care about": Authentic inquiry learning and student experiences of an inquiry project. Anat. Sci. Educ. 10, 538-548. https://doi.org/10.1002/ase.1690

Biru, L.T., Prasetyaningsih, P., Vitasari, M., Resti, V.D.A., Suryani, D.I., 2018. The Implementation of Pedagogical Content Knowledge (PCK) based Guided Inquiry on Science Teacher Students. J. Penelit. Dan Pembelajaran IPA 4, 76. https://doi.org/10.30870/jppi.v4i1.3315

Brown, D., Chronister, C., 2009. The Effect of Simulation Learning on Critical Thinking and Selfconfidence When Incorporated Into an Electrocardiogram Nursing Course. Clin. Simul. Nurs. 5, e45-e52. https://doi.org/10.1016/j.ecns.2008.11.001

Chang, C., Chang, C.-K., Shih, J.-L., 2016. Motivational strategies in a mobile inquiry-based language learning setting. System 59, 100-115. https://doi.org/10.1016/j.system.2016.04.013 
Cheng, P.-H., Yang, Y.-T.C., Chang, S.-H.G., Kuo, F.-R.R., 2016. 5E Mobile Inquiry Learning Approach for Enhancing Learning Motivation and Scientific Inquiry Ability of University Students. IEEE Trans. Educ. 59, 147-153. https://doi.org/10.1109/TE.2015.2467352

Hartini, I., 2016. Keefektifan Pembelajaran Inkuiri dan Problem-Based Learning terhadap Hasil Belajar Siswa Pada Mata Pelajaran Ilmu Pengetahuan Alam 8.

Hsu, L., 2014. An epistemological analysis of the application of an online inquiry-based program in tourism education. Australas. J. Educ. Technol. 30. https://doi.org/10.14742/ajet.402

Inche,E and Acar,Y.,2016. Analysis Of The Effect Of Prediction-Observation-Explanation And Inquiry-Based Learning Methods On Scientific Process Skills And Critical Thinking Disposition Of Preservice Science Teachers In General Physics Laboratory.

Istikomayanti, Y., Si, S., 2015. Penerapan Strategi Inkuiri Dan Problem Based Learning (Pbl) Untuk Meningkatkan Pemahaman Konsep Dan Keterampilan Proses Pada Mata Kuliah Ekologi Tumbuhan Berbasis Ptk-Ls 7.

Kocagül, M. 2013. Effects of Inquiry Professional Development Activities on Scientific Process Skills of Primary School Science and Technology Teachers, Self-Efficacy and Beliefs on Inquiry-Based Learning. Dokuz Eylül University Institute of Educational Sciences, İzmir.

National Research Council, 2000. Inquiry and the National Science Education Standards. Washington, DC: National Academy Press

Nybo, L., May, M., 2015. Effectiveness of inquiry-based learning in an undergraduate exercise physiology course. Adv. Physiol. Educ. 39, 76-80. https://doi.org/10.1152/advan.00161.2014

Putra, H.D., Purwasih, R., 2015. Meningkatkan Prestasi Belajar Dan Keaktifan Mahasiswa Melalui Project Based Learning 2, 9.

Sari, N., 2015. Penggunaan Model Inquiry Learning Untuk Meningkatkan Hasil Belajar Siswa 13.

Smallhorn, M., Young, J., Hunter, N., Burke da Silva, K., 2015. Inquiry-based learning to improve student engagement in a large first year topic. Stud. Success 6. https://doi.org/10.5204/ssj.v6i2.292

Triyana,E.,2017.Efektifitas Model Pembelajaran Guided Inquiry Dan Model Problem Based Learning (PBL) Terhadap Kemampuan Pemecahan Masalah Pada Mata Pelajaran Matematika.

Ural, E., 2016. The Effect of Guided-Inquiry Laboratory Experiments on Science Education Students' Chemistry Laboratory Attitudes, Anxiety and Achievement. J. Educ. Train. Stud. 4. https://doi.org/10.11114/jets.v4i4.1395

Wang, H.-Y., Duh, H.B.-L., Li, N., Lin, T.-J., Tsai, C.-C., 2014. An Investigation of University Students' Collaborative Inquiry Learning Behaviors in an Augmented Reality Simulation and a Traditional Simulation. J. Sci. Educ. Technol. 23, 682-691. https://doi.org/10.1007/s10956-0149494-8

Wu,J.W.,Tseng,J.C.R,\& Hwang,G.J.,2015. Development Of An Inquiry-Based Learning Support System Based On An Inteligent Knowledge Exploration Approach.Educational Tecnology\&Society, 18(3),282-300

Yildirim, N., Kurt, S., Güneş, L., 2014. Effects Of Inquiry Based Learning Activities On Scientific Process Skills And Academic ACHIEVEMENT OF PRESERVICE CLASSROOM TEACHERS. Int. J. Acad. Res. 6, 9.

Yunistika, R., Juanengsih, N., 2018. Enhancing Students' Higher-Order Thinking Skills Through Guided and Free Inquiry-Based Learning 115, 4. 
